\title{
Characterization of Protein-like Fluorophores Released from Lake Phytoplankton on the Basis of Fractionation and Electrophoresis
}

\author{
Etsu YAMAda, $* 1, * 2 \dagger$ Takaaki HIRota, $* 2$ Naoko Hatori, ${ }^{* 2}$ Yuki KITAO, ${ }^{* 2}$ Yasuro FuSE, ${ }^{* 1}$ \\ Shinichi AOKI, ${ }^{* 3}$ Hajime KARATANI, ${ }^{* 4}$ and Toshiro MATSUNAGA ${ }^{* 5}$ \\ *1 Center for Environmental Science, Kyoto Institute of Technology, Matsugasaki, Sakyo, Kyoto 606-8585, Japan \\ *2 Department of Chemistry and Material Technology, Kyoto Institute of Technology, Matsugasaki, Sakyo, \\ Kyoto 606-8585, Japan \\ *3 Lake Biwa Environmental Research Institute (LBERI), Yanagasaki, Otsu, Shiga 520-0022, Japan \\ *4 Department of Biomolecular Engineering, Kyoto Institute of Technology, Matsugasaki, Sakyo, \\ Kyoto 606-8585, Japan \\ *5 National Agricultural Research Center, National Agriculture and Food Research Organization, Tsukuba, \\ Ibaraki 305-8666, Japan
}

\begin{abstract}
Three kinds of lake plankton were cultivated, and the properties of protein-like fluorophores released from the plankton were characterized using sodium dodecyl sulfate-polyacrylamide gel electrophoresis (SDS-PAGE). The results were compared with those by gel chromatography with a fluorescence detector and three-dimensional excitation-emission matrix (3-DEEM). The concentrated protein-like fluorophores of algal dissolved organic matter (DOM) were successfully separated from the fulvic-like fluorophores, and analyzed using SDS-PAGE. SDS-PAGE analysis revealed that the protein-like fluorescence DOM released from Microcystis aeruginosa consisted of proteins with molecular weights of 17, $37,50,75,150 \mathrm{kDa}$, and greater than $250 \mathrm{kDa}$. The results of SDS-PAGE were consistent with those of gel chromatography. Those substances with molecular weights greater than $250 \mathrm{kDa}$ may be a polysaccharide-peptide complex, called peptidoglycan, which is a component of bacterial cell walls. The molecular weights of protein-like fluorescence DOM from Staurastrum dorsidentiferum were determined to be 37 and $50 \mathrm{kDa}$. For Cryptomonas ovata, its DOM was found to be composed of substances with molecular weights of between 10 and $150 \mathrm{kDa}$. The results by high-performance size exclusion chromatography with chemiluminescent nitrogen detection (HPSEC/CLND) analysis suggest that the proteinlike fluorophores from the plankton might be composed of substances containing organic nitrogen.
\end{abstract}

(Received March 7, 2012; Accepted April 16, 2012; Published June 10, 2012)

\section{Introduction}

In Lake Biwa, the largest lake in Japan, it has been observed that the chemical oxygen demand (COD) has risen year after year since 1985, although the values of biochemical oxygen demand (BOD) and chlorophyll- $a$ have been almost constant. However, the values of COD in the rivers flowing into Lake Biwa have not increased. ${ }^{1}$ These results suggest that refractory organic matter has gradually accumulated in Lake Biwa. Seasonal and vertical variations in the concentrations of dissolved organic carbon (DOC) and organic substances, such as dissolved carbohydrates, have been examined to clarify the causes. $^{2-4}$ In several lakes, chemical fractionation methods have been applied to analyze the temporal changes of DOC. ${ }^{5-9}$ The natural carbon stable isotope ratio of DOC has been used to identify DOC sources in aquatic systems..$^{10,11}$ This approach was used to examine relative contributions of autochthonous and allochthonous sources to dissolved organic matter (DOM) in Lake Biwa. ${ }^{12,13}$

$\dagger$ To whom correspondence should be addressed.

E-mail: eyamada@kit.ac.jp
In our previous study, DOM in Lake Biwa and rivers was investigated so as to elucidate its origins and behavior. The main origin of hydrophobic acids in Lake Biwa may be humic substances from soils around rivers that flow into Lake Biwa, while hydrophilic DOM may be due to inner production by phytoplankton. ${ }^{14-17}$ However, few studies about the contribution of inner production by phytoplankton to DOM have been carried out, ${ }^{18}$ therefore, three kinds of lake phytoplankton, Microcystis aeruginosa, Staurastrum dorsidentiferum, and Cryptomonas ovata were cultivated, and the contribution of DOM released from the phytoplankton was examined to clarify the origin of the organic pollution of Lake Biwa with regard to cultivation and biodegradation. ${ }^{19-21}$ The characteristics of the algal-derived DOM were investigated using gel chromatography with a fluorescence detector and a three-dimensional excitation-emission matrix (3-DEEM) technique. As a result, the algal DOM released from the plankton during cultivation makes an important contribution to the accumulation of the refractory organic matter in Lake Biwa. Furthermore, the fulvic-like fluorescence DOM from three kinds of plankton shows fluorescence similar in spectral distribution to that from the soil FA, but exhibits mainly hydrophilic characteristics. The protein-like fluorescence DOM released from Microcystis 
aeruginosa may be mainly hydrophobic DOM with a considerably large molecular weight. ${ }^{19,20}$

In the present study, the properties of protein-like fluorophores released from three kinds of lake plankton during cultivation were characterized on the basis of the molecular weight using sodium dodecyl sulfate-polyacrylamide gel electrophoresis (SDS-PAGE) of algal-derived DOM prepared using an ultrafiltration membrane. Furthermore, the validity of the obtained results was confirmed by comparing the results by gel chromatography with a fluorescence detector and 3-DEEM. However, since it is uncertain whether the detected bands or peaks contain organic nitrogen $(\mathrm{N})$, protein-like fluorophores released from Microcystis aeruginosa were analyzed by using high-performance size exclusion chromatography with chemiluminescent nitrogen detection (HPSEC/CLND). ${ }^{22-24}$

\section{Experimental}

\section{Reagents and apparatus}

Three kinds of phytoplankton, Microcystis aeruginosa (NIES-109, Lake Yogo, Shiga), Staurastrum dorsidentiferum (NIES-665, Lake Biwa, Shiga), and Cryptomonas ovata (NIES-275, Tsuchiura, Ibaraki), which were supplied by the National Institute for Environmental Studies, were used. ${ }^{19-21}$

Humic and fulvic acids obtained from A-horizons of brown forest soil (Dystric Cambisol, Dando, Aichi, Japan) were used. Dando humic and fulvic acids prepared according to the methods developed by the International Humic Substances Society (IHSS) were supplied by the Japan Humic Substances Society, and used as a standard without further purification. All other chemicals were of the best commercial grade available. Pure water was prepared using a Millipore Milli-Q water purification system.

An Olympus IX71N-22PH-D microscope was used to count the number of algae cells. The apparatus used for HPLC was a Shimadzu LC-10AD chromatography pump equipped with a Shimadzu RF-10A $\mathrm{xL}$ fluorescence detector. The excitation and emission wavelengths were 340 and $435 \mathrm{~nm}$, respectively. A Shimadzu C-R7A Chromatopac was used for data analysis. The test samples were applied to a gel filtration column, Superose12 HR10/30 $(300 \times 10 \mathrm{~mm}$ i.d.; Pharmacia Biotech $)$, using a sample injector (Rheodyne 7125) with a $100-\mu$ loop. A $0.01 \mathrm{M}$ sodium hydroxide solution was used as an eluent at a flow rate of $0.4 \mathrm{ml} \mathrm{min}{ }^{-1}$. A TOC meter (Shimadzu TOC-V CSH) was used for the determination of DOC. A Shimadzu UV-160A spectrophotometer was used for measuring the UV-absorbance $(260 \mathrm{~nm})$ of water samples. A Kubota KN-70 centrifuge and a Hitachi Koki Himac CR20GIII refrigerated centrifuge were used for the fractionation and concentration of algal DOM, respectively. A Horiba F-51 pH meter and a TOA CM-60S EC meter were used for measuring the $\mathrm{pH}$ and electric conductivity, respectively.

\section{Cultivation of phytoplankton}

Three kinds of phytoplankton were cultivated in an improved VT medium. Microcystis aeruginosa and Staurastrum dorsidentiferum were grown in one liter $(1 \mathrm{~L})$ triangular flasks at $20^{\circ} \mathrm{C}$ and 2000 lux under a $12 \mathrm{~h}: 12 \mathrm{~h}$ light/dark cycle. Cryptomonas ovata was grown in a 1-L triangular flask at $15^{\circ} \mathrm{C}$ and 2000 lux under the same light/dark cycle.

The changes in time of BOD, COD, DOC, and E260 (absorbance at $260 \mathrm{~nm}$ ) were measured in the cultivation. Dissolved organic substances were analyzed using gel chromatography with a fluorescence detector developed for the simultaneous determination of the concentration and molecular weight of humic substances. ${ }^{15}$

The fluorescence properties of algal DOM were measured with a three-dimensional excitation-emission matrix (3-DEEM) using a fluorescence spectrophotometer, a Shimadzu RF-5300PC enabling high-resolution fluorescence measurement by running with band-pass-width slits of $5 \mathrm{~nm}$ for both excitation and emission. The excitation and emission wavelengths were scanned from 220 to $500 \mathrm{~nm}$ and from 250 to $600 \mathrm{~nm}$ with a wavelength scan speed of $1500 \mathrm{~nm} / \mathrm{min}$. Fluorescence readings were normalized by the fluorescence intensity (Ex = $345 \mathrm{~nm} / \mathrm{Em}=450 \mathrm{~nm})$ of $10 \mu \mathrm{g} / \mathrm{l}$ quinine sulfate $(0.05 \mathrm{M}$ $\mathrm{H}_{2} \mathrm{SO}_{4}$ solution) $10 \mathrm{QSU}$. The values were treated as the relative fluorescence intensity (RFI).

\section{Concentration of algal DOM using an ultrafiltration membrane} and electrophoresis

On days 30 and 42 for Microcystis aeruginosa, 77 and 80 for Staurastrum dorsidentiferum, and 47 and 67 for Cryptomonas ovata, each $350 \mathrm{ml}$ (or $200 \mathrm{ml}$ ) of harvested growth media including algal cells was centrifuged at $1.3 \mathrm{kG}$ and $4^{\circ} \mathrm{C}$ for $5 \mathrm{~min}$. Each supernatant was concentrated to $3 \mathrm{ml}$ on a Millipore ultrafiltration membrane (molecular weight cut-off $[\mathrm{MWCO}]=10 \mathrm{kDa}$ ) at a pressure of $0.5 \mathrm{MPa}$ with stirring. The concentrated sample solution ( $3 \mathrm{ml}$ ) was loaded on an Econopack $10 \mathrm{DG}$ column $([\mathrm{MWCO}]=6 \mathrm{kDa}$, Bio-Rad) to exchange the buffer solution; $3 \mathrm{ml}$ of the eluate was dumped. Subsequently, the algal DOM of interest was eluted with $4 \mathrm{ml}$ of a Tris- $\mathrm{HCl}$ buffer. A 4-ml volume of the eluate was further concentrated by using an Amicon Ultra ultrafiltration tube $([\mathrm{MWCO}]=1 \mathrm{kDa}$, Millipore) with centrifugation at $1.3 \mathrm{kG}$ and $4^{\circ} \mathrm{C}$. Finally, each $350 \mathrm{ml}$ of the harvested growth media containing algal DOM was concentrated to about $1 \mathrm{ml}$, and the concentrated protein-like fluorescence DOM was fully separated from other low-molecular weight substances.

The concentrated protein-like fluorophores of algal DOM were subjected to SDS-PAGE to analyze the protein-like components. A mixture of a $16-\mu 1$ concentrated sample solution and $4 \mu \mathrm{l}$ of a loading buffer, consisting of $62.5 \mathrm{mM}$ Tris- $\mathrm{HCl}$ (pH 6.8), 25\% glycerol, 2\% SDS, 5\% 2-mercaptoethanol and $0.01 \%$ bromophenol blue, was heated at $80^{\circ} \mathrm{C}$ for $5 \mathrm{~min}$. Fifteen microliters of each sample solution and $7 \mu \mathrm{l}$ of a molecular weight marker (Bio-Rad, Precision Plus Protein standards) as standards $(10,15,20,25,37,50,75,100,150$, and $250 \mathrm{kDa})$ were loaded onto each lane of a 1-mm gel in $15 \%$ acrylamide gel (Atto PAGEL) and subjected to $300 \mathrm{~V}$ (20 mA) for $75 \mathrm{~min}$. Subsequently, the gel was stained using the Coomassie Brilliant Blue (CBB).

\section{Fractionation of algal DOM and 3-DEEM}

Fractionation of algal DOM was carried out using Amicon Ultra ultrafiltration tubes of three different MWCOs: 30, 10, and $3 \mathrm{kDa}$. The $10-\mathrm{ml}$ sample solution containing algal DOM was centrifuged on each MWCO membrane at $1.5 \mathrm{kG}$ for $15 \mathrm{~min}$ $(30$ and $10 \mathrm{kDa})$ or $35 \mathrm{~min}(3 \mathrm{kDa})$. The fractionation of algal DOM (1 kDa) was carried out on a Millipore ultrafiltration filter (molecular weight cut-off $[\mathrm{MWCO}]=1 \mathrm{kDa}$ ) at the pressure of $0.5 \mathrm{MPa}$ with stirring, followed by the fluorescence characterization by 3-DEEM.

High-performance size exclusion chromatography and chemiluminescent nitrogen detection (HPSEC/CLND) analysis

On day 51 for Microcystis aeruginosa, a 100-ml of harvested growth media including algal cells was filtered through a membrane filter $(0.45 \mu \mathrm{m}$, Millipore). The filtrate was 
Table 1 Relationship between molecular weight and fluorescence intensities of the fluorophores released from three kinds of phytoplankton

\begin{tabular}{|c|c|c|c|c|c|c|c|c|}
\hline \multirow{3}{*}{$\begin{array}{l}\text { Molecular } \\
\text { weight/ } \\
\mathrm{kDa}\end{array}$} & \multicolumn{8}{|c|}{ Fluorescence intensity/QSU } \\
\hline & \multicolumn{3}{|c|}{ Peak A } & \multicolumn{3}{|c|}{ Peak B } & \multicolumn{2}{|c|}{ Peak C } \\
\hline & M & $S$ & $\mathrm{C}$ & M & $S$ & $\mathrm{C}$ & $\mathrm{M}$ & $S$ \\
\hline$>30$ & $\begin{array}{c}3.5 \\
(7.7)\end{array}$ & $\begin{array}{c}10.6 \\
(12.2)\end{array}$ & $\begin{array}{c}9.4 \\
(13.2)\end{array}$ & $\begin{array}{c}10.1 \\
(14.9)\end{array}$ & $\begin{array}{c}18.6 \\
(21.9)\end{array}$ & $\begin{array}{c}15.6 \\
(16.4)\end{array}$ & $\begin{array}{l}165.9 \\
(88.6)\end{array}$ & $\begin{array}{l}196.9 \\
(88.2)\end{array}$ \\
\hline $10-30$ & $\begin{array}{c}1.7 \\
(3.8)\end{array}$ & $\begin{array}{c}1.7 \\
(2.0)\end{array}$ & $\begin{array}{c}0.9 \\
(1.3)\end{array}$ & $\begin{array}{c}1.8 \\
(2.7)\end{array}$ & $\begin{array}{c}2.1 \\
(2.5)\end{array}$ & $\begin{array}{c}13.5 \\
(14.2)\end{array}$ & $\begin{array}{c}2.7 \\
(1.4)\end{array}$ & $\begin{array}{c}0.3 \\
(0.1)\end{array}$ \\
\hline $3-10$ & $\begin{array}{c}4.8 \\
(10.6)\end{array}$ & $\begin{array}{c}4.8 \\
(5.5)\end{array}$ & $\begin{array}{c}7.5 \\
(10.6)\end{array}$ & $\begin{array}{c}8.6 \\
(12.7)\end{array}$ & $\begin{array}{c}1.5 \\
(1.8)\end{array}$ & $\begin{array}{c}17.5 \\
(18.4)\end{array}$ & $\begin{array}{c}1.0 \\
(0.5)\end{array}$ & $\begin{array}{c}0.8 \\
(0.4)\end{array}$ \\
\hline $1-3$ & $\begin{array}{c}19 \\
(41.9)\end{array}$ & $\begin{array}{c}24 \\
(27.6)\end{array}$ & $\begin{array}{c}53.2^{\mathrm{a}} \\
(74.9)\end{array}$ & $\begin{array}{c}25.8 \\
(38.0)\end{array}$ & $\begin{array}{c}19.9 \\
(23.5)\end{array}$ & $\begin{array}{l}48.5^{\mathrm{a}} \\
(51.0)\end{array}$ & $\begin{array}{c}10 \\
(5.3)\end{array}$ & $\begin{array}{c}6.1 \\
(2.7)\end{array}$ \\
\hline$<1$ & $\begin{array}{c}16.3 \\
(36.0)\end{array}$ & $\begin{array}{c}45.8 \\
(52.7)\end{array}$ & & $\begin{array}{c}21.6 \\
(31.8)\end{array}$ & $\begin{array}{c}42.7 \\
(50.4)\end{array}$ & & $\begin{array}{c}7.6 \\
(4.1)\end{array}$ & $\begin{array}{l}19.2 \\
(8.6)\end{array}$ \\
\hline
\end{tabular}

The values in parentheses are the ratios (\%).

M, Microcystis aeruginosa; S, Staurastrum dorsidentiferum; C, Cryptomonas ovata.

a. $<3 \mathrm{kDa}$.

concentrated to $3 \mathrm{ml}$ by freeze drying. The concentrated sample solution $(3 \mathrm{ml})$ was loaded on an Econopack 10 DG column ([MWCO] $=6 \mathrm{kDa}, \mathrm{Bio}-\mathrm{Rad}$ ), and then exchanged the buffer solution with $4 \mathrm{ml}$ of a Tris- $\mathrm{HCl}$ buffer. A 4-ml volume of the eluate was further concentrated by using an Amicon Ultra ultrafiltration tube ([MWCO $]=3 \mathrm{kDa}$, Millipore) with centrifugation at $1.3 \mathrm{kG}$ and $4^{\circ} \mathrm{C}$. Finally, $100 \mathrm{ml}$ of the harvested growth media containing algal DOM was concentrated to about $1 \mathrm{ml}$. The concentrated protein-like fluorophores of algal DOM was separated by HPSEC using a YMC-Pack Diol 200 column (a silica based column, $8 \mathrm{~mm} \times 300 \mathrm{~mm}$ ) and a HPLC system (LC-2000, JASCO) equipped with a ultraviolet (UV)-visible detector (UV-2070, JASCO) set at $280 \mathrm{~nm}$, and a chemiluminescent nitrogen detector (ANTEK 8060, PAC, USA). A $50 \mathrm{mM}$ sodium acetate/acetic acid buffer ( $\mathrm{pH} 7$ ) was used as the eluent. The flow rate was $1 \mathrm{ml} \mathrm{min}^{-1}$, and at the outlet of the column, $250 \mu 1 \mathrm{~min}^{-1}$ of the eluent flow was split into the CLND detector. The CLND detector conditions were as follows: argon, $50 \mathrm{ml} \mathrm{min}{ }^{-1}$; oxygen, $250 \mathrm{ml} \mathrm{min}^{-1}$; ozone, $25 \mathrm{ml} \mathrm{min}^{-1}$; oven temperature, $1050^{\circ} \mathrm{C}$. The sample volume injected was $100 \mu 1 .{ }^{23,24}$

\section{Results and Discussion}

\section{Fractionation of algal DOM}

In a previous study, ${ }^{19,20}$ Microcystis aeruginosa, Staurastrum dorsidentiferum, and Cryptomonas ovata were cultivated, and the contribution of dissolved organic matter (DOM) released from the phytoplankton was evaluated by gel chromatography with a fluorescence detector $(\mathrm{Ex}=340 \mathrm{~nm}, \mathrm{Em}=435 \mathrm{~nm})$. As a result, the algal DOM released from plankton during cultivation mainly gives rise to a significant peak $\left(M_{\mathrm{W}}:<3 \mathrm{kDa}\right)$. Since this peak is in good agreement with one of three chromatographic peaks clearly detected in the surface water of Lake Biwa, it can be concluded that the algal DOM released from the plankton during cultivation makes an important contribution to the refractory organic matter in Lake Biwa. From the spectral base characterization, the cultivation of three kinds of phytoplankton was found to yield two fulvic-like fluorescence peaks (A and B) (a)

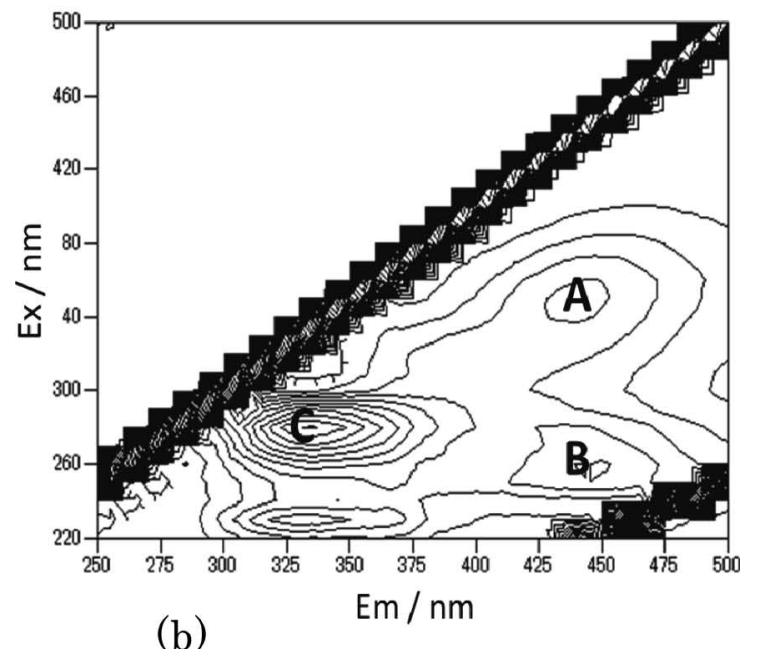

(b)

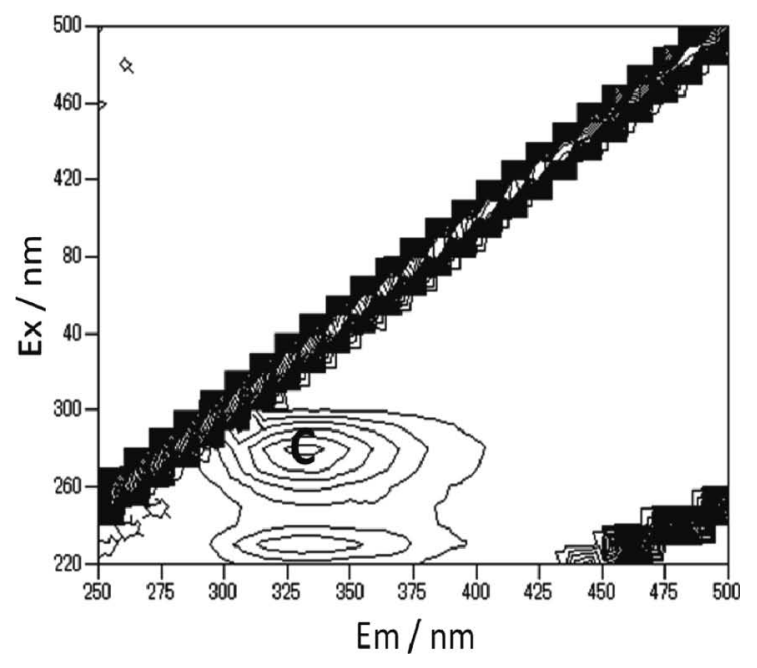

Fig. 1 3-DEEM contour plots of algal DOM from Microcystis aeruginosa before (a) and after (b) the gel filtration using an Econopack 10-DG column ([MWCO] $=6 \mathrm{kDa})$. A, B, fulvic-like fluorescence peaks; $\mathrm{C}$, protein-like fluorescence peak.

and a protein-like fluorescence peak (C). The fulvic-like fluorescence DOM (peak A) from Microcystis aeruginosa may be due to the relatively small molecular weight, as compared with those of the soil FA, while protein-like fluorescence DOM (peak C) is anticipated to be arising from a considerably large substance. ${ }^{19}$

To clarify this, first, algal DOM from three kinds of plankton was fractionated by the ultrafiltration and characterized in detail in the present study (Table 1). Table 1 summarizes the relationship between the molecular weight of the components and their fluorescence properties. The molecular weight of over $70 \%$ of fulvic-like fluorescence DOM (peaks A and B) from the plankton was estimated to be less than $3 \mathrm{kDa}$. These results were consistent with those obtained by gel chromatography. The molecular weight of protein-like fluorescence DOM (peak C) for Microcystis aeruginosa and Staurastrum dorsidentiferum was estimated to be over $30 \mathrm{kDa}$. Gel chromatograms of algal DOM from Microcystis aeruginosa at Ex/Em wavelength of peak $\mathrm{C}$ showed a large peak at retention time $(\mathrm{RT})=17-18 \mathrm{~min}$ and several small peaks at 32, 35, and $47 \mathrm{~min}$. Based on the calibration curve for molecular-weight standards, the peaks 


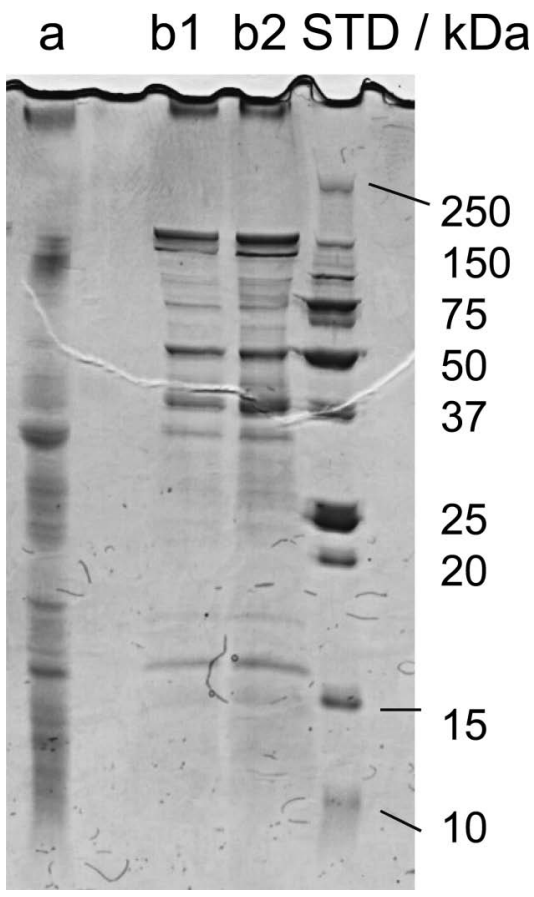

Fig. 2 SDS-PAGE analysis of the concentrated algal DOM released from Microcystis aeruginosa before (a) and after (b1, b2) the gel filtration using a 10-DG column. STD, marker; cultivation, 30 days.

detected at $17-18,32$, and $35 \mathrm{~min}$ corresponded to the molecular weights of about $200,3-5$, and $<3 \mathrm{kDa}$, respectively.

\section{SDS-PAGE of concentrated protein-like fluorescence DOM from} Microcystis aeruginosa

No bands were detected in the algal DOM without any concentration-treatment with SDS-PAGE. Thus, the untreated algal DOM was considered to contain a considerably small amount of protein-like fluorescence DOM. Therefore, we used ultrafiltration for concentration, and exchanged the VT media with a Tris-buffer to remove interfering substances by using 10-DG column prior to the SDS-PAGE analysis. 3-DEEM contour plots of algal DOM from Microcystis aeruginosa before and after gel filtration using a 10-DG column are shown in Fig. 1. Two fulvic-like fluorescence peaks (A and B) and a protein-like fluorescence peak (C) were detected before gel filtration, but it should be noted that only a protein-like fluorescence peak (C) was detected after gel filtration. These results indicate that only protein-like fluorescence DOM can be isolated from fulvic-like fluorescence DOM with this step.

The SDS-PAGE patterns of the concentrated algal DOM from Microcystis aeruginosa (cultivation 30 days) before and after the gel filtration using a 10-DG column are shown in Fig. 2. The observation that the lane of the sample before the gel filtration gave rise to an unclear band pattern might be due to many contaminants. Conversely, clear bands corresponding to the positions at approximately $17,37,50,75$, and $150 \mathrm{kDa}$ were observed in the lanes of the buffer exchanged sample after the gel filtration, and the bands around 37 and $150 \mathrm{kDa}$ were fairly clear. The protein-like fluorescence DOM from Microcystis aeruginosa may comprise a mixture of substances with diverse MWs. Since a clear band was observed at the top of the sample lane, the protein-like fluorescence DOM is considered to consist of substances with a molecular weight greater than $250 \mathrm{kDa}$. This is consistent with the results of gel chromatography that
Table 2 Molecular weights of protein-like fluorescence substances released from three kinds of phytoplankton by SDSPAGE

\begin{tabular}{lcl}
\hline \multicolumn{1}{c}{ Phytoplankton } & $\begin{array}{c}\text { Cultivation/ } \\
\text { day }\end{array}$ & $\begin{array}{c}\text { Molecular weight } \\
\text { of protein/kDa }\end{array}$ \\
\hline Microcystis aeruginosa & 30 & $17,37,50,75,150,>250$ \\
Staurastrum dorsidentiferum & 42 & $15-20,50,150,>250$ \\
& 80 & 37,50 \\
Cryptomonas ovata & 47 & $50-150$ \\
& 67 & $10,15,37,75,150$ \\
\hline
\end{tabular}

the protein-like fluorescence DOM from Microcystis aeruginosa had a large molecular weight of greater than $200 \mathrm{kDa} .{ }^{19}$ The algal DOM from Microcystis aeruginosa on day $42 \mathrm{had}$ molecular weight of between 15 and 20,50, $150 \mathrm{kDa}$ and more than $250 \mathrm{kDa}$ (Table 2). The substances with large molecular weights might be peptidoglycans, which are components of bacterial cell walls..$^{25}$

Since mass propagation of algae in drinking-water source affects the coagulation process in water-treatment systems, it is highly desirable to establish effective countermeasures against such coagulation inhibition. In this context, it is crucial to identify any causative substances released from algae. ${ }^{26,27}$ Microcystis aeruginosa was cultivated, and recovered organic matters from the culture were analyzed using gel chromatography and SDS-PAGE. ${ }^{28,29}$ The results of gel chromatography showed that algal organic matters (AOMs) have various molecular weights of between 10 and $20 \mathrm{kDa}$, around $40 \mathrm{kDa}$, and greater than $600 \mathrm{kDa}$. SDS-PAGE analysis showed that AOMs included components that are able to form complexes with aluminum; such components have molecular weights between 43 and $67 \mathrm{kDa} .^{28,29}$ These results are in good agreement with ours as stated above.

\section{SDS-PAGE of concentrated protein-like fluorescence DOM from} Staurastrum dorsidentiferum and Cryptomonas ovata

The SDS-PAGE electrophoretograms of the concentrated algal DOM from Microcystis aeruginosa (M), Staurastrum dorsidentiferum (S), and Cryptomonas ovata (C) are shown in Fig. 3. The molecular weights of protein-like fluorescence substances released from the three planktons by SDS-PAGE analysis are listed in Table 2. Two clear bands corresponding to the positions at 37 and $50 \mathrm{kDa}$ were observed in the lane of the concentrated algal DOM from Staurastrum dorsidentiferum, and the band at $50 \mathrm{kDa}$ was much clear. A smear electrophoretic band pattern split into several bands at approximately 10, 15, 37,75 , and $150 \mathrm{kDa}$ was observed in the lane of the concentrated algal DOM from Cryptomonas ovata on day 67. Several unclear bands between 50 and $150 \mathrm{kDa}$ were observed in the lane of the concentrated algal DOM from Cryptomonas ovata on day 47. As the band at greater than $250 \mathrm{kDa}$ was not observed at the top of each lane for Staurastrum dorsidentiferum and Cryptomonas ovata, substances with a large molecular weight of greater than $250 \mathrm{kDa}$ may not be present in both algal DOM, which significantly differs from the case of Microcystis aeruginosa. The bands of Cryptomonas ovata were not clear relative to those of Microcystis aeruginosa and Staurastrum dorsidentiferum. This is possibly not only because the protein-like fluorescence substances released from Cryptomonas ovata might have been decomposed, but also because those released from Microcystis aeruginosa and Staurastrum dorsidentiferum could be relatively refractory. ${ }^{30}$ Furthermore, the effects of cultivation days and 


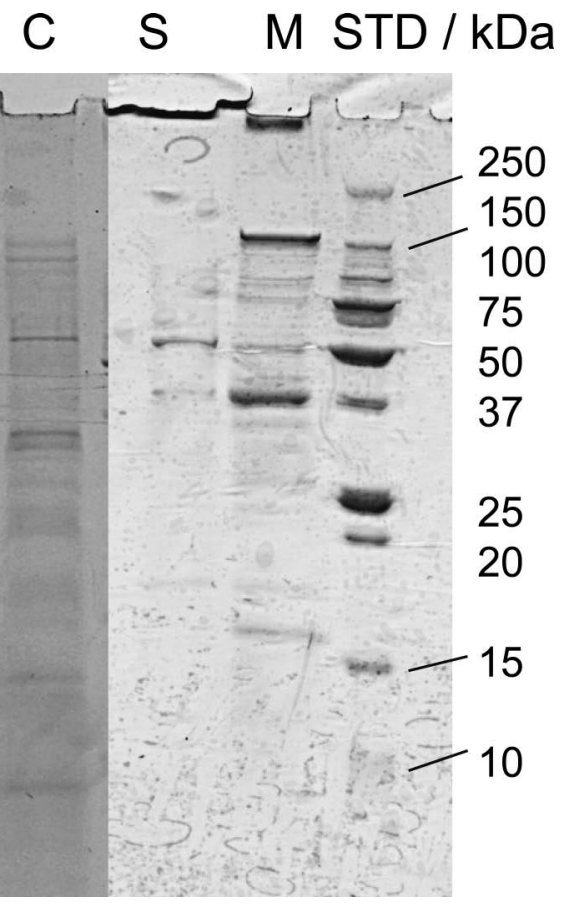

Fig. 3 SDS-PAGE analysis of the concentrated algal DOM from Microcystis aeruginosa (M), Staurastrum dorsidentiferum (S) and Cryptomonas ovata (C) during cultivation for 30, 77 and 67 days, respectively.

preconcentration on the properties of protein-like fluorescence DOM should be examined because their molecular weights, and fluorescence may change during cultivation or the process of preconcentration.

\section{HPSEC/CLND analysis of concentrated protein-like fluorescence DOM from Microcystis aeruginosa}

Furthermore, to make clear that the protein-like fluorophores of algal DOM contain organic N, HPSEC/CLND was applied to analyze the concentrated protein-like fluorescence DOM released from Microcystis aeruginosa. By HPSEC/CLND analysis, each $\mathrm{N}$-containing compound eluted from an HPLC column was introduced into a furnace at $1050^{\circ} \mathrm{C}$ and oxidized to nitric oxide (NO), and then determined using a chemiluminescence detector with ozone. ${ }^{22,23}$ Figure 4(a) shows chromatogram of protein standards by HPSEC/CLND analysis. Thyroglobulin $(660 \mathrm{kDa})$, ovalbumin $(45 \mathrm{kDa})$, myoglobin $(17 \mathrm{kDa})$ and vitamin B-12 (1.4 kDa) were detected at 6.2, 8.5, 10.9 and $11.9 \mathrm{~min}$, respectively. The chromatograms of the concentrated protein-like fluorescence DOM from Microcystis aeruginosa recorded by CLND and by UV absorbance at 280 $\mathrm{nm}$ are shown Figs. 4(b) and 4(c), respectively. A significant peak at $6.1 \mathrm{~min}$ and several small peaks between 7 and $11 \mathrm{~min}$ were observed in both chromatograms, showing that $\mathrm{N}$-containing DOM has molecular weights ranging from 10 to $660 \mathrm{kDa}$. A large peak between 12 and 20 min observed in the $\mathrm{N}$ chromatogram from the HPSEC/CLND analysis is likely to be attributed to Tris- $\mathrm{HCl}$ buffer in which the concentrated algal DOM was dissolved. From these results, the protein-like fluorescence DOM from plankton might be composed of polypeptide-like substances containing organic N. An analysis of the protein-like fluorescence DOM, including the determination of the $\mathrm{N}$-amino acid sequences, will be conducted in the further study.
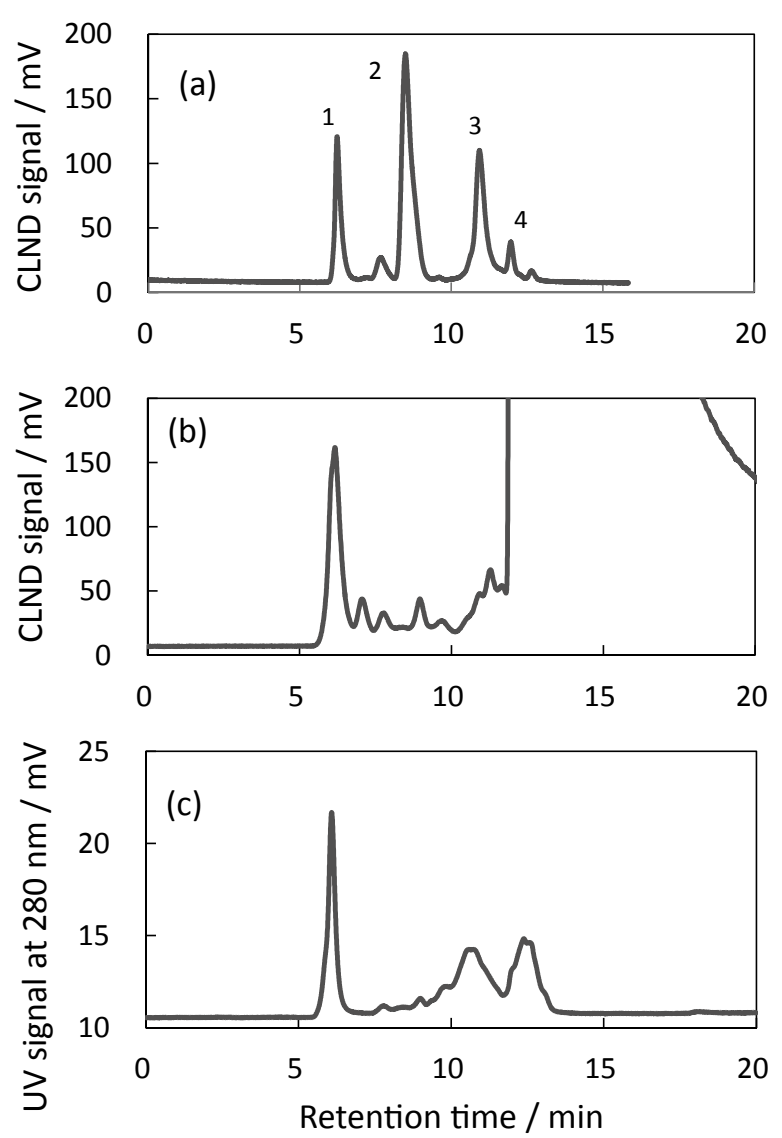

Fig. 4 High-performance size-exclusion chromatograms of protein standards (a) and the concentrated algal DOM from Microcystis aeruginosa on day 51 (b) (c) recorded by different detection methods. (a), (b) Chemiluminescent nitrogen detector (CLND), (c) UV detector at $280 \mathrm{~nm}$. Injection volume: (a) $10 \mu \mathrm{l} ; 1$, thyroglobulin $(660 \mathrm{kDa}$, $1.9 \mu \mathrm{g}) ; 2$, ovalbumin $(45 \mathrm{kDa}, 3.6 \mu \mathrm{g})$; 3 , myoglobin $(17 \mathrm{kDa}$, $2.3 \mu \mathrm{g}) ; 4$, vitamin B-12 (1.4 kDa, $0.32 \mu \mathrm{g})$, (b) (c) $100 \mu \mathrm{l}$.

\section{Acknowledgements}

The present study was supported by a Grant-in-Aid for Scientific Research from the Ministry of Education, Culture, Sports, Science and Technology (Nos. 17310008 and 23510006).

\section{References}

1. Shiga Prefecture, Kankyohakusyo, 2011, 42.

2. K. Hayakawa, Org. Geochem., 2004, 35, 169.

3. K. Hayakawa, Research Report of Lake Biwa Environmental Research Institute, 2005, 22, 161.

4. K. Amano, K. Matsumoto, A. Imai, and K. Matsushige, Jpn. J. Limnol., 2004, 27, 659.

5. H. Tatsumoto, T. Hattori, T. Furukawa, I. Ikushima, M. Kurihara, and I. Abe, Nippon Kagaku Kaishi, 1991, 852.

6. A. Imai, T. Fukushima, K. Matsushige, T. Inoue, and T. Ishibashi, Jpn. J. Limnol., 1998, 59, 53.

7. T. Hori, Y. Sugiyama, and M. Sugiyama, Jpn. J. Limnol., 1998, 59, 39.

8. Y. Sugiyama, M. Sugiyama, and T. Hori, Limnology, 2000, $1,171$.

9. Y. Sugiyama and T. Kumagai, Anal. Sci., 2001, 17, 77. 
10. P. A. Raymond and J. E. Bauer, Limnol. Oceanogr., 2001, 46, 655.

11. S. E. Ziegler and S. L. Brisco, Hydrobiologia, 2004, 513, 153.

12. C. Kim, Y. Nishimura, and T. Nagata, Limnol. Oceanogr., 2006, 51,70 .

13. K. Maki, C. Kim, C. Yoshimizu, I. Tayasu, T. Miyajima, and T. Nagata, Limnology, 2010, 11, 143.

14. E. Yamada, T. Ozaki, and M. Kimura, Anal. Sci., 1998, 14, 327.

15. E. Yamada, K. Doi, K. Okano, and Y. Fuse, Anal. Sci., 2000, 16, 125.

16. S. Aoki, Y. Fuse, and E. Yamada, Anal. Sci., 2004, 20, 159.

17. K. Nagai, S. Aoki, Y. Fuse, and E. Yamada, Bunseki Kagaku, 2005, 54, 923.

18. C. Yoshimizu, T. Yoshida, M. Nakanishi, and J. Urabe, Limnology, 2001, 2, 37.

19. S. Aoki, S. Ohara, K. Kimura, H. Mizuguchi, Y. Fuse, and E. Yamada, Anal. Sci., 2008, 24, 389.

20. S. Aoki, S. Ohara, K. Kimura, H. Mizuguchi, Y. Fuse, and E. Yamada, Anal. Sci., 2008, 24, 1461.
21. S. Ohara, T. Uehara, K. Kimura, T. Yoshida, S. Fujiwara, Y. Mizuguchi, Y. Fuse, and E. Yamada, Bunseki Kagaku, 2009, 58,231

22. E. Fujinari and J. Damon, J. Chromatogr., A, 1997, 763, 323.

23. M. Morizumi and T. Matsunaga, Soil Sci. Plant Nutr., 2011, 57, 185

24. D. Corens, M. Carpentier, M. Schroven, and L. Meerpoel, J. Chromatogr., A, 2004, 67, 1056.

25. W. Amelung, J. Plant. Nutr. Soil, 2003, 166, 677.

26. C. W. K. Chow, M. Drikas, J. House, M. D. Burch, and R. M. A. Velzeboer, Water Res., 1999, 33, 3253.

27. M. Z. B. Alam, M. Otaki, H. Furumai, and S. Ohgaki, Water Res., 2001, 35, 1008.

28. T. Takaara, D. Sano, H. Konno, and T. Omura, Wat. Sci. Technol-Water, 2004, 4, 95.

29. S. Ishifuji, Y. Sato, H. Imae, T. Takaara, D. Sato, Y. Masago, and T. Omura, J. Jpn. Soc. Wat. Environ., 2010, 33, 73.

30. S. Ohara, T. Uehara, S. Aoki, Y. Fuse, and E. Yamada, Abstracts of 58th Conference of the Japan Society for Analytical Chemistry, 2009, 25. 